\title{
MEMBONGKAR IDENTITAS DALAM FILM "WANDU"
}

\author{
Ghalif Putra Sadewa \\ Mahasiswa Penciptaan Seni Videografi \\ Program Pascasarjana ISI Yogyakarta \\ Jalan Suryodiningratan No. 8, Mantrijeron, Yogyakarta \\ No. Hp.: +6289647223140,E-mail: ghalifputra@ymail.com
}

\begin{abstract}
ABSTRAK
"Wandu" ("The Effeminate") adalah film pendek televisi yang bercerita tentang problematika tiga orang waria dalam proses pencarian identitas dan haknya sebagai manusia di tengah masyarakat yang majemuk. Penolakan aspirasi waria dan citra negatif telah melekat erat di masyarakat dan berdampak di segala sepak terjang waria. Semua waria sama saja, itulah ungkapan yang jamak. Diskriminasi, upaya penolakan, dan perlakuan yang tidak manusiawi merupakan tekanan sosial yang terjadi akibat nihilnya identitas bagi waria. Oleh sebab itu, identitas menjadi hal terpenting bagi waria. Identitas adalah bentuk keberadaan yang konkret untuk mendapatkan kesejahteraan sosial yang lebih baik dan setara.
\end{abstract}

Kata kunci: identitas, film "Wandu", waria

\section{ABSTRACT}

Revealing Identity in "Wandu" the Movie. "Wandu" ("The Effeminate") is a television short film that tells about the problems of three transvestites in the process of searching for their identities and rights as human beings amid a plural society. The rejection of transvestite aspirations and negative image has been firmly attached to the community and it has an impact on all transvestites. All transvestites are the same, that is a common phrase. Discrimination, refusal, and inhuman treatment are social pressures resulting from the lack of identity for transvestites. Therefore, identity becomes the most important thing for transvestites. Identity is a concrete form of existence to achieve a better and equal social welfare.

Keywords: identity, "Wandu” the movie, effeminate

\section{PENDAHULUAN}

"Wandu" ("The Effeminate") merupakan film pendek berdurasi 25.50 menit yang mengambil latar belakang cerita di Yogyakarta tahun 2016. Film ini berbicara tentang diskriminasi yang jamak dirasakan kalangan waria. Kejamakan inilah yang membuat stigma masyarakat akan waria sama rata. Waria merupakan salah satu penyandang masalah kesejahteraan sosial di Indonesia, baik ditinjau dari segi psikologis, sosial, norma, fisik, bahkan keberadaannya sebagai manusia masih dipertanyakan.
Makna hidup adalah hal-hal yang oleh seseorang dipandang penting, dirasakan berharga dan diyakini sebagai sesuatu yang benar serta dapat dijadikan tujuan hidupnya (Bastaman, 1996:211).

Adanya suatu dorongan fundamental yang dimiliki oleh manusia, yaitu kehendak untuk memaknai hidup karena makna dan nilai hidup bersifat menuntut atau menarik manusia untuk memenuhinya serta bukan semata-mata ungkapan keberadaan. Penemuan makna hidup 
menjadikan kehidupan manusia berarti dan berharga.

Yogyakarta dipilih sebagai latar belakang film karena ketiga tokoh serta sumber cerita dalam film "Wandu" berasal dari kota ini. Dilansir dari Ikatan Waria Yogyakarta(IWAYO) pada tahun 2016, jumlah waria di Yogyakarta sekitar 223 orang dan diperkirakan jumlahnya akan bertambah. Yogyakarta dipandang sebagai kota toleran bagi kaum marginal ini. Apalagi dengan berdirinya dua tempat singgah yang sudah familiar di kalangan waria. Yayasan Kebaya yang berada di Jalan Gowongan Lor No. 148, Yogyakarta dan juga Pondok Pesantren Waria Al Fatah di Kota Gede yang belakangan ini sedang redup dan sempat ditutup oleh beberapa pihak karena merasa terganggu dengan keberadaan pondok pesantren tersebut.

Menjalani hidup sebagai waria dan melakukan aktivitas di tengah masyarakat majemuk tentu tidak mudah. Sebagaimana diketahui oleh masyarakat, waria tidak mendapatkan tempat yang layak, status sosial yang jelas, dan permasalahan identitas diri. Identitas menjadi sesuatu yang penting bagi setiap individu tidak terkecuali untuk waria. Bahkan untuk bergabung dalam IWAYO pun waria harus memiliki kartu identitas sebagai salah satu persyaratannya. Hal ini untuk meninjau serta mendata asal dan latar belakang dari waria yang bergabung. Dalam skala yang lebih luas lagi, identitas yang dimaksud bukan hanya selembar kertas, melainkan sebuah pengakuan dan kesetaraan hak dalam lingkup sosial yang umum.

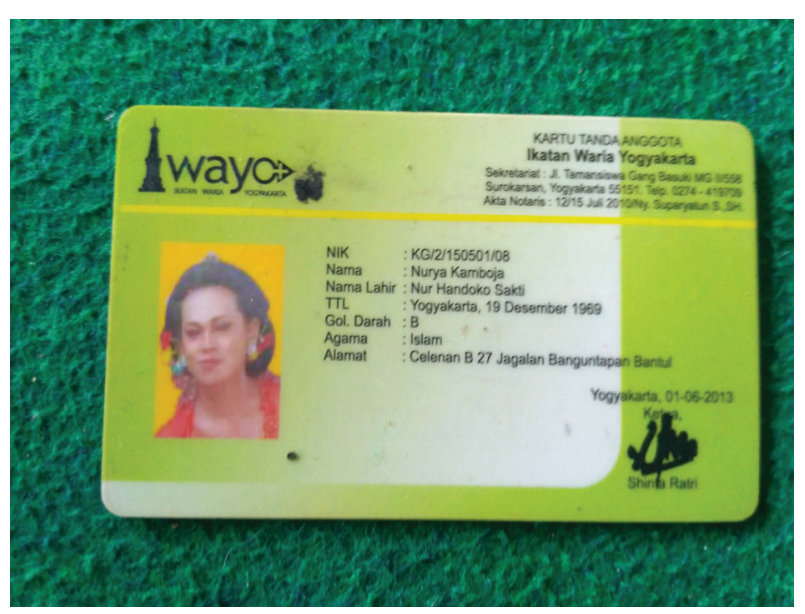

Gambar 1 Kartu Tanda Anggota Ikatan Waria Yogyakarta (Aryandi Muhammad / Dokumen Kompasiana)

Adam dan Gullota dalam El-Idhami (2005) menuturkan bahwa identitas adalah sebuah fenomena psikologi yang kompleks. Sebuah cara pemikiran seseorang dalam kepribadiannya sendiri dan orang lain di sekitarnya. Termasuk di dalamnya identifikasi dengan individu yang dianggap penting dalam kehidupan dari awal masa kanak-kanak. Termasuk identifikasi peranan seks, ideologi individu, penerimaan norma kelompok, dan banyak lagi. Identitas sangat dipengaruhi oleh pribadi sebagai pelaku. Dengan kata lain, untuk dapat menjadi sesuatu seringkali seseorang harus melakukan sesuatu dan menjadi sesuatu. Identitas bisa berbentuk kebangsaan, ras, etnik, kelas pekerjaan, agama, umur, gender, suku, keturunan, dan lain-lain. Pendekatan dalam identitas diri ataupun sosial erat kaitannya dengan hubungan inter relationship, serta kehidupan alamiah masyarakat dan lingkungan sosialnya. Hal inilah yang ditunjukkan dalam film "Wandu". Menghadirkan tiga sosok waria dengan persoalan yang berbeda dan berjalan bersama dalam satu kesatuan waktu membuat film ini seakan-akan hanya mengangkat satu permasalahan yang sama, identitas.

Film "Wandu" memilih gaya multiplot untuk bertutur. Cerita dibangun dari persoalan 
yang sering timbul dalam masyarakat umumnya. Persoalan pengurusan surat identitas, kamar mandi di tempat umum, stigma masyarakat, dan persoalan yang lebih kompleks, yaitu kematian. Setiap permasalahan yang dihadapi oleh waria pasti tidak jauh-jauh dari masalah identitas dan kesetaraan sosial hingga pada jasadnya nanti. Identitas yang dianggap amat sederhana menjadi hal penting bagi waria karena tanpa kejelasan identitas maka berdampak pada status sosial di masyarakat dan hak-hak sebagai manusia.

\section{TINJAUAN PUSTAKA}

\section{Identitas}

\begin{abstract}
Identity is a complex psychological phenomenon. It might be thought of as the person in personality. It includes our own interpretation of early childhood identification with important individual in our lives. It includes a sense of identity integrates sex-role identification, individual ideology, accepted group norms and standards, and much more (El-Idhami 2005: 211).
\end{abstract}

Kutipan tersebut menyimpulkan bahwa identitas adalah sebuah fenomena psikologi kompleks. Sebuah cara pemikiran seseorang dalam kepribadiannya sendiri dan orang lain di sekitarnya. Termasuk di dalamnya identifikasi dengan individu yang dianggap penting dalam kehidupan dari awal masa kanakkanak. Termasuk juga identifikasi peranan seks, ideologi individu, penerimaan norma kelompok, dan banyak lagi.

Identitas berarti memiliki gambaran diri yang jelas meliputi sejumlah tujuan, nilai, dan kepercayaan dalam setiap individu. Konsep ini mengacu pada pertanyaan "siapakah saya?", yang di dalamnya tercakup label-label dan simbol-simbol yang diberikan kepada diri oleh individu bersangkutan untuk menggambarkan dirinya dan membangun identitasnya. Dengan kata lain, untuk dapat menjadi sesuatu seringkali seseorang harus melakukan sesuatu dan menjadi sesuatu. Identitas bisa berbentuk kebangsaan, ras, etnik, kelas pekerjaan, agama, umur, gender, suku, keturunan, dan lain-lain. Pendekatan dalam identitas diri dan sosial erat kaitannya dengan hubungan inter-relationship, serta kehidupan alamiah masyarakat dan lingkungan sosialnya.

Dalam film televisi "Wandu" ketiga tokoh waria bercerita tentang pengalaman mereka mencari dan menemukan identitas yang ada di dalam masyarakat. Melalui konflik buang air kecil di kamar mandi umum, proses pengurusan surat untuk BPJS, hingga proses pemandian dan pemakaman jenazah adalah sederet persoalan identitas bagi waria. Bagaimanapun juga, identitas menjadi hal penting dalam segala hal dan hak sebagai manusia pada umumnya.

\section{Waria}

Jumlah kaum waria memang tidak terlalu besar jika dibandingkan dengan populasi masyarakat pada umumnya, namun dalam beberapa hal dunia mereka telah mendatangkan atau menjadi tolak ukur problematika yang tidak sederhana. Hal ini terkait persoalan keberadaan dan eksistensi kaum marginal dalam upaya mencari ruang-ruang dalam lingkup sosial. Tidak heran jika pergerakan mereka yang masif menyebar di berbagai daerah. Meskipun tidak selalu dapat penolakan dari warga setempat ataupun kelompok tertentu nyatanya ini adalah bagian kecil yang mungkin saja belum tersentuh tepatnya. 
Fakta menunjukkan bahwa bagian terbesar dari mereka memiliki pekerjaan sebagai pelacur. Meskipun banyak di antara mereka bekerja di berbagai bidang, seperti salon kecantikan, pembantu rumah tangga, berdagang, atau pekerjaan-pekerjaan lain, akan tetapi dunia pelacuran tetap sulit mereka tinggalkan begitu saja (Atmojo, 1986:25-26).

Waria merupakan kelompok marginal sasaran kesejahteraan sosial. Menurut Friedlander dalam (Salamah 2012), kesejahteraan sosial merupakan sistem yang terorganisasi dari institusi dan pelayanan sosial yang dirancang untuk membantu individu ataupun kelompok agar dapat mencapai standar hidup dan kesehatan yang lebih memuaskan. Berdasar teori tersebut, jika pelayanan sosial mampu menjangkau kelompok marginal, dapat dikatakan bahwa tingkat kesejahteraan sosial tinggi karena salah satu bagian dari kesejahteraan sosial yaitu pelayanan sosial telah mampu menjangkau kelompok terbawah lapisan masyarakat.

Persoalan pelayanan sosial, hak dasar untuk merasa aman, dan memperoleh hak sebagai manusia pada umumnya tidak dirasakan oleh ketiga waria dalam film televisi "Wandu". Jaminan rasa aman dan nyaman justru berbanding terbalik bagi Sani saat buang air kecil di salah satu pusat perbelanjaan karena Sani adalah waria. Pelayanan sosial yang harusnya menyeluruh tanpa tebang pilih tidak dirasakan Ayu ketika mengurus surat identitas diri untuk proses BPJS karena Ayu waria dengan label negatif. Stigma masyarakat juga menimpa jenazah Kemmy, dari proses pemandian hingga pemakaman tidak semudah masyarakat umum lainnya karena dia waria.

\section{METODE PENELITIAN}

Berbekal riset sejak tahun 2014 tentang persoalan waria di Indonesia khususnya Yogyakarta, serta citra yang ada di masyarakat maka penulis mulai membuat struktur cerita berdasarkan kisah nyata. Dari meninggalnya waria bernama Mita (Eko Slamet Putranto), 33 tahun yang ditemukan jenazahnya di daerah Kalasan pada 16 Februari 2013 atas dugaan korban pembunuhan (Kusuma 2013) dan juga penolakan jenazah waria Mayang Prasetyo di Bandarlampung pada tahun 2014 membuat rasa empati waria tergugah. Persoalan diskriminasi bagi kaum waria bukan hanya verbal, namun hingga pada tataran saat waria meninggal. Dari penuturan kalangan waria terutama pengurus Yayasan Kebaya yang lebih akrab dipanggil Mami, penulis mendapatkan banyak gambaran ketidakadilan yang kerap mereka rasakan sebagai kaum "LGBT". Diskriminasi ini terjadi baik di tempat umum maupun di tempat pelayan masyarakat. Ihwal perlakuan diskrimnasi waria di Yogyakarta bahkan sudah sampai di DPD Yogyakarta.

GKR Hemas selaku Wakil Ketua DPD pun meninjau ulang implementasi aturan yang bernada intoleran (Nurrizki, 2015). Kecenderungan aksi diskriminasi dan cemooh terhadap kaum waria didorong faktor rendahnya moral dan empati masyarakat. Di Jogja, tempat penulis melalukan proses kreatif dalam mengembangkan gagasan tentang problematika waria dan identitas, memang hal sensitif tentang LGBT tidak pernah benarbenar padam. Penolakan waria dan berbagai spanduk yang cenderung menyudutkan dan bersifat provokatif kerap terpampang di berbagai sudut kota. Tidak pelak hal ini justru membentuk stigma masyarakat akan waria menjadi tergiring opini publik tanpa pernah 
sempat mengetahui lebih jauh siapa waria itu sebenarnya. Begitu mudah mendapat gambaran kehidupan waria merupakan indikasi dunia waria tidak terpisahkan dari masyarakat, dan masalah-masalah mereka pasti berpengaruh pada kelompok masyarakat lain.

Dunia waria, wadam, atau banci bagi banyak orang merupakan bentuk kehidupan anak manusia yang cukup aneh. Secara fisik mereka adalah laki-laki normal, memiliki kelamin yang normal, namun secara psikis mereka merasa dirinya perempuan, tidak ubahnya seperti kaum perempuan lainnya (Koeswinarno, 2004:1).

Penolakan dalam beragam aksi di Yogyakarta yang secara frontal ditujukan pada LGBT terus mengalir dari waktu ke waktu. Aksi damai kaum LGBT memprotes maraknya kasus intoleran dan kekerasan disambut dengan demo dan ancaman yang membabi buta. Negara tidak betul-betul memerhatikan persoalan identitas bagi waria. Rasa aman yang harusnya mereka dapat dari kelompok intoleran yang semakin merajalela justru menjadi bom waktu yang siap meletus kapan saja. Publik digiring ke arah pro dengan intoleran dalam konteks waria dan mengecam waria dalam segala bentuk sisi dan merampas hak mereka adalah persoalan sosial serius yang harus ditemukan solusinya.

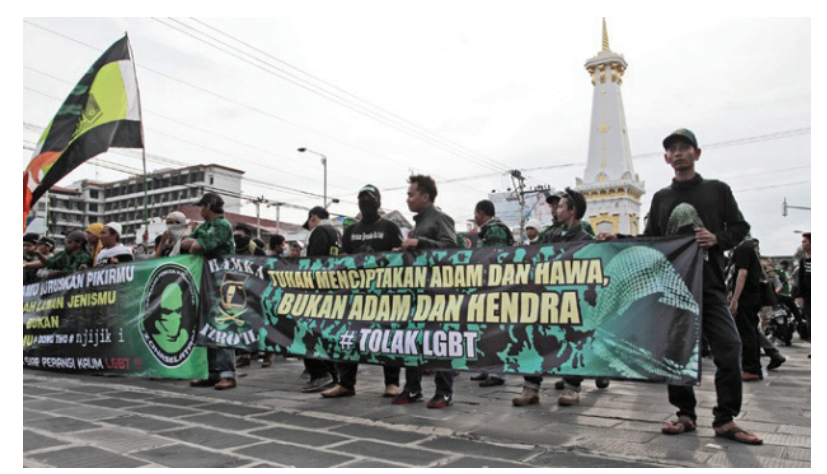

Gambar 2 Gerakan Pemuda Penolak LGBT di Yogyakarta tahun 2016 (Dokumen Pius Erlangga / Nasional Tempo)
Jumlah kaum waria memang tidak terlalu besar jika dibandingkan dengan populasi masyarakat pada umumnya, namun dalam beberapa hal dunia mereka telah mendatangkan atau menjadi tolak ukur problematika yang tidak sederhana. Pelayanan sosial mampu diukur dan dikatakan berhasil jika menyentuh lapisan sosial masyarakat suatu daerah tanpa perbedaan. Jika pelayanan sosial masih terhalang atau justru tidak berimbang, kesenjangan sosial terjadi di lingkungan tersebut. Waria merupakan kelompok marginal yang menjadi sasaran kesejahteraan sosial. Persoalan pelayanan sosial, hak dasar untuk merasa aman, dan memperoleh hak sebagai manusia pada umumnya tidak dirasakan oleh ketiga waria dalam film "Wandu".

\section{PEMBAHASAN}

\section{Berkenalan dengan Film "Wandu"}

Identitas film

$\begin{array}{ll}\text { Durasi } & : 26 \text { menit } \\ \text { Produksi } & : \text { Hitam Putih film } \\ \text { Tahun } & : 2016 \\ \text { Latar cerita } & \text { : Yogyakarta, Indonesia } \\ \text { Dialog } & \text { : Indonesia } \\ \text { Subtitle } & \text { : Inggris } \\ \text { Format } & \text { : MOV } \\ \text { Warna } & \text { : Warna } \\ \text { Suara } & \text { : Stereo } \\ \text { Apresiasi } & \text { : } \\ \text { 1. Official Selection Shanghai Pride Film } \\ \text { Festival 2017 } & \\ \text { 2. Semi-Finalist Caribbean Film Festival } \\ \text { \& Market } 2017 \\ \text { 3. Official Selection Geo Film Festival } \\ \text { 2nd Edition } 2017\end{array}$


Skenario "Wandu"

a. Penulisan Skenario "Wandu"

Ide cerita film televisi "Wandu" berawal dari kegelisahan tentang keberadaan waria yang sampai saat ini masih berjuang mencari keadilan identitas. Dalam prosesnya sutradara turut membantu dalam pembuatan naskah "Wandu". Melakukan riset, wawancara dengan narasumber untuk memasukkan konflik yang terjadi kedalam alur cerita. Tiga ide cerita yang ditulis dan dikembangkan menjadi cerita selanjutnya berdasarkan kisah nyata yang sutradara dan penulis naskah temukan selama riset dilapangan, paguyuban waria, dan komunitas waria.

b. Premis

Premis penciptaan karya seni film televisi "Wandu" adalah problematika tiga waria yang ingin diakui identitas dan hak dalam masyarakat, tetapi mendapatkan penolakan. Melalui premis ini, pengembangan ke dalam bentuk visual juga disesuaikan. Pemilihan waria sebagai tokoh cerita berpacu pada kehidupan realita dan konflik yang dialami dalam kehidupan sosial masyarakat.

c. Sinopsis film televisi "Wandu"

Wandu menggambarkan tiga waria yang berjuang memperoleh pengakuan identitas dalam masyarakat. Sani (35 tahun), Kemmy (28 tahun), dan Ayu (29 tahun) adalah waria yang tidak mendapatkan keadilan dalam hak sebagai manusia. Sani mendapatkan perlakuan kurang menyenangkan saat di toilet pusat perbelanjaan. Keinginan buang air kecilnya harus berurusan panjang. Seorang ibu (Rina) yang juga pengguna toilet mencurigai kehadiran Sani di toilet wanita. Perdebatan dan stigma negatif mengucur deras dari mulut Rina, tentang keburukan dan perilaku tidak wajar seorang waria. Satpam mal yang harusnya menjadi pihak netral justru ikut memojokkan Sani. Persoalan identitas juga dialami Ayu saat mengurus surat bantuan guna proses BPJS dan perihal ganti kelamin di KTP-nya. Ketidakcocokan surat keterangan Akta dan kondisi Ayu membuat petugas menolak permintaan Ayu. Di sisi lain, Ayu juga dikejar waktu untuk mengurus pekerjaannya. Keterangan identitas dan jenis kelamin sangat diperlukan Ayu untuk mendapatkan pekerjaan yang telah lama ia harapkan. Sisi kepedihan juga menimpa jenazah Kemmy, kakaknya (Suryo) tidak mau memandikan jenazah Kemmy karena ia waria. Suryo mencari bantuan warga, namun tidak ada yang sudi datang dan memandikan. Beberapa warga yang datang di rumah Kemmy hanya membicarakan pandangan mereka akan waria dan tetap menolak untuk memandikan jenazah. Lastri (ibu Kemmy) sedih melihat kondisi yang terjadi, hari semakin gelap namun jenazah belum dimandikan.

\section{d. Alur/Plot}

Pola struktur yang digunakan dalam film televisi "Wandu" adalah 
struktur multiplot. Penggunaan multiplot sering dihubungkan dengan satu tema atau tujuan yang kuat untuk menjaga hubungan kausalitasnya (Pratista, 2008:48). Dalam film televisi "Wandu" keterkaitan tokoh satu dengan yang lain ditunjukkan dengan tema persoalan yang mereka hadapi, yaitu krisisnya pengakuan masyarakat akan waria dan hak dasar yang tidak diperoleh waria sebagai manusia.

Penerapan alur multiplot sangat membantu dalam meningkatkan dramatik antaradegan karena dalam film ini setiap tokoh memiliki persoalan yang berbeda, namun satu gagasan tentang keberadaan diri. Selain berfungsi dalam merajut konflik, multiplot sangat berperan dalam proses proyeksi persoalan tokoh. Penonton dipaksa masuk ke dalam tiga persoalan sekaligus tanpa diberi waktu untuk menebak, apakah ini satu cerita atau tiga cerita yang berjalan bersama dengan satu tema? Hingga di akhir film, ketiga tokoh tidak dimasukkan dalam satu frame, melainkan berdiri sendiri-sendiri dengan penyelesaian sendiri-sendiri pula.

e. Konflik

Konflik besar dalam film televisi "Wandu" adalah pertanyaan tentang identitas dan hak yang harusnya diperoleh manusia pada umumnya, termasuk waria di dalamnya. Pemecahan konflik besar selalu membawa perubahan penting, baik dalam diri tokoh maupun tokoh-tokoh lain yang terlibat dalam cerita. Konflik besar dan penyelesaiannya dapat memberikan sumbangan besar pada pengalaman penonton.

Konflik bisa dibangun dari mana saja, salah satunya keberadaan manusia. Jaminan rasa aman dan nyaman justru berbanding terbalik bagi Sani saat buang air kecil di salah satu pusat perbelanjaan karena Sani adalah waria. Pelayanan sosial yang harusnya menyeluruh tanpa tebang pilih tidak dirasakan Ayu ketika mengurus surat identitas diri untuk proses BPJS karena Ayu waria yang memiliki label negatif. Stigma masyarakat akan manusia yang aneh dan tidak wajar juga dialami Kemmy, meskipun Kemmy sudah meninggal namun proses pemandian hingga pemakaman tidak semudah masyarakat umum lainnya karena Kemmy waria.

\section{Kemmy: Dari Memandikan Hingga Penolakan Pemakaman}

Loyalitas hubungan erat keluarga antara ibu dan anak tergambar pada Lastri yang tetap bersikukuh ingin memandikan Kemmy di rumahnya. Keadaan Kemmy yang sudah tidak normal membuat Suryo harus mencari warga yang rela membantu. Kemmy tumbuh di keluarga yang memegang prinsip agama dengan kuat dan besar di lingkungan yang menilai paham bahwa waria adalah orang yang "tidak pada umumnya". Seburuk apa pun keadaannya dan sejauh mana seseorang melangkah, ibu adalah kepulangan yang tidak pernah menutup pintunya. Perbedaan pilihan dan kontras situasi ditunjukkan dengan penempatan ornamenornamen agama sebagai bentuk perlawanan sekaligus pergulatan. 


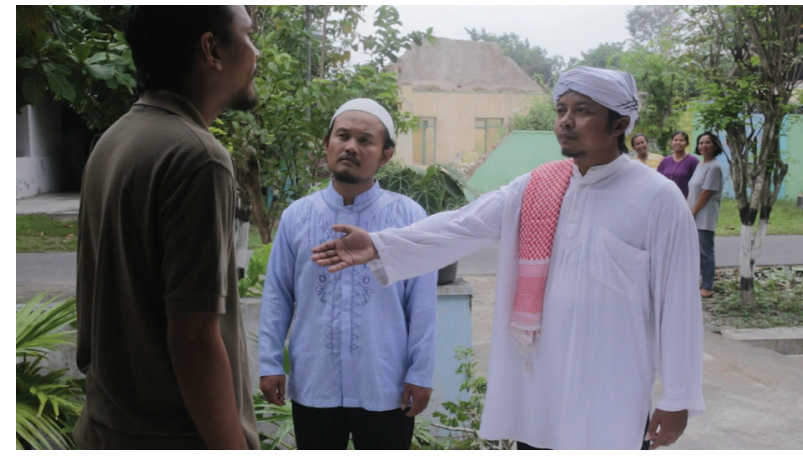

Gambar 3 Salah satu adegan warga menolak jenazah Kemmy (dokumen pribadi)

Perlawanan Lastri dalam mencari identitas sosial anaknya digambarkan dengan usaha-usaha yang muncul di seluruh film "Wandu". Diawali dengan meminta Suryo mencari bantuan warga, menjelaskan kepada tetangga bahwa anaknya bukan mati karena HIV hingga pada ketidakpastian saat perwakilan warga menolak jenazah Kemmy. Lastri merupakan sosok ibu yang sangat menyayangi anaknya. Apa pun keadaan seorang anak, ibu akan tetap menyayangi.

Begitu pula Lastri. Prinsip seorang ibu yang teguh, sabar, dan sangat sayang ditunjukkan Lastri. Bahkan saat tidak ada lagi yang mau menerima Kemmy, Lastri yang meminta dan menerima keadaan anaknya. Proses pengakuan keberadaan yang tidak mudah, namun tidak lantas membuat Lastri menyerah akan identitas Kemmy.

Begitu pula Suryo, sikap sayang kepada adiknya dan rasa kehilangan tidak ditunjukkan kepada Lastri karena ia tahu bagaimana perasaan Lastri saat adiknya meninggal. Suryo adalah sosok anak sekaligus kakak yang berbakti kepada Lastri. Meskipun berat hati, ia menuruti keinginan ibunya untuk meminta tolong warga. Di sisi lain Suryo sangat sedih dengan kematian adiknya. Ia juga begitu sayang kepada Kemmy dan juga keluarganya. Terlebih saat tetangga mengira Kemmy terkena HIV dan saat petugas
TPU menolak jenazah Kemmy. Di sini terlihat bagaimana Suryo begitu keras membela adiknya dan menjaga perasaan ibunya, Lastri.

$$
\text { Perlawanan Suryo adalah citra }
$$
perlawanan kaum LGBT di tengah minimnya tempat dan rasa aman. Ancaman intoleran tidak lagi berbetuk verbal namun tindakan nyata, mengesampingkan perihal sosial manusia. Serentetan kisah Kemmy adalah gambaran bagaimana waria masih memiliki banyak penolakan di masyarakat, sekalipun ia sudah meninggal. Urusan waria tidak akan berhenti bagi kaum intoleran. Melihat sisi kemanusian tidak lagi dibutuhkan bagi proses penilaiannya. Kisah ini juga mengingatkan kembali akan isu yang terjadi di masyarakat Indonesia. Kaum LGBT adalah sampah masyarakat dan tidak ada tempat bagi mereka. Perihal waria manusia dan memiliki hak asasi manusia yang sama adalah fatamorgana saja. Lalu bagaimanakah jika salah satu dari LGBT itu adalah anggota keluarga. Sisi kemanusiaan selayaknya diutamakan dalam hal ini.

\section{Ayu: Dari Struktur yang Tidak Lengkap Hingga Proses Suap}

Penciptaan itu merupakan cara yang memungkinkan sesuatu muncul, yakni kebenaran, yang mewujudnyatakan diri kalau diberikan peluang (Hauskeller, 2015:79). Identitas menjadi hal penting dalam kehidupan.

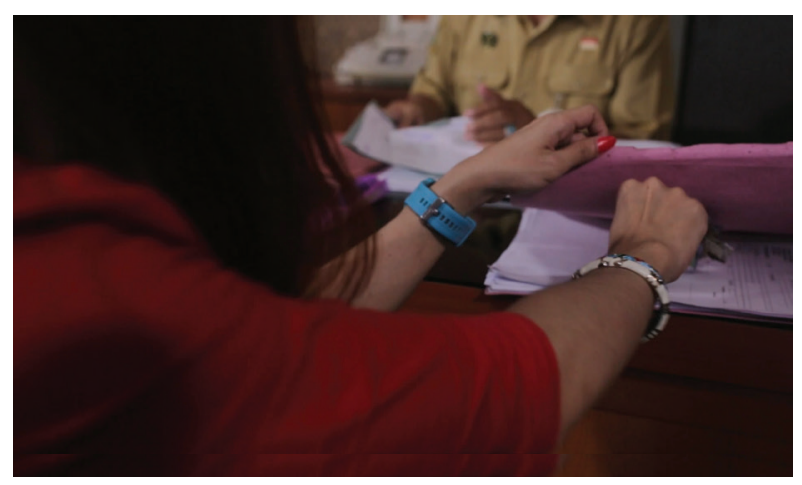

Gambar 4 Adegan Ayu memasukkan lembaran uang ke dalam map (dokumen pribadi) 
Baik identitas yang berbentuk surat (KTP, KK, dan lainnya) maupun pengakuan jati diri di masyarakat. Ayu adalah potret kecil dari waria yang sering dipandang masyarakat dengan stigma negatif. Pembentukan karakter Ayu yang kelas bawah, tidak mengenal sopan santun, dan acak-acakan menjadi potret stigma bahwa semua waria sama, yaitu PSK. Kesenjangan sosial dan menjadi objek yang selalu diperhatikan serta menjadi barang olokan membuat waria seperti Ayu bertingkah menggoda dan selalu ingin menjadi fokus di segala tempat ia berada. Proses pengurusan kartu identitas adalah bentuk upaya Ayu memperoleh hak layaknya masyarakat lain. Keberadaan yang menjamin rasa aman dari segala bentuk ancaman. Namun, persoalan berkas yang tidak lengkap dan struktur yang salah membuat Ayu tidak bisa mengurus KTPnya. Tidak hanya itu, adegan Ayu menyuap petugas kelurahan adalah hal yang sering terjadi dewasa ini.

Membongkar wajah kepalsuan dan menyuguhkan realitas yang terjadi merupakan persoalan yang gampang-gampang susah. Suap dan korupsi bukan lagi tindak kejahatan yang tidak disengaja atau seseorang terjebak dalam pusaran tersebut, melainkan kebutuhan yang harus segera diwujudkan. Tidak heran jika segala hal yang didampingi dengan suap akan cepat. Persoalan utamanya bukan disuap atau korupsi barangkali, namun lebih bobroknya moralitas bangsa. Suap-menyuap layaknya budaya yang harus dilestarikan di berbagai kalangan termasuk instansi. Untuk mempermudah proses pengurusan tidak jarang warga dan petugas bekerja sama agar berkas yang dibutuhkan lancar sekalipun itu tidak sesuai dengan peraturan yang ada. Kenyataan yang sangat memprihatinkan jika melihat indikasi seperti ini mengakar di masyarakat. Dalam adegan Ayu tentang perihal suap bukan merupakan tolak ukur waria bisa memperoleh identitas dengan seketika, namun menunjukkan bagaimana hal jamak ini terjadi di kalangan pemerintahan. Ayu memberanikan menyuap petugas tentu bukan didasari dia seorang waria yang tidak mempunyai moral dan etika, tetapi lebih apa yang dia lihat dan dia amati tentang kultur sosialnya.

Tindakan kreatif acap bermula dari melihat hal-hal biasa, lumrah, atau yang tadinya bukan apa-apa. Melalui pengamatan, yang biasa akan menjadi luar biasa (Marianto, 2017:122).

Barangkali pengamatan seniman tentang proses suap yang sering terjadi dan menghiasi layar kaca menjadi gagasan sekaligus perlawanan melalui tokoh Ayu. Atau, bisa saja seniman ingin mengatakan bahwa seseorang yang melakukan suap-menyuap sama saja seperti waria yang tidak punya identitas jati diri manusia dan tidak diakui keberadaannya. Tentu hal ini memiliki banyak perspektif. Penggunaan uang pecahan dan disisipkan ke dalam map seakan berbicara tentang harapan dan sebuah keyakinan semacam doa layaknya seseorang yang datang ke pesta perkawinan dengan membawa amplop berisi uang. Keberanian Ayu menyuap petugas dengan terang-terangan juga bentuk protes keras seniman kepada segala bentuk KKN. Semakin memudarnya rasa malu, ketidakadilan, dan rasa tidak menghargai di masyarakat justru menjadi cerminan pola pikir lingkup sosial tempat masyarakat tinggal. Diskriminasi dan suap tidak memandang tempat dan ruang di mana harus terjadi dan dengan apa harus dilakukan, semuanya tentang kebutuhan dan ideologi yang terbentuk di masing-masing individu melalui pengalaman dan pengamatan akan suatu rutinitas. 
Sani: Stigma Masyarakat yang Keliru dan Satpam yang Tidak Adil

Menurut Noah Webster dalam Fuady (2002), justice merupakan bagian dari sebuah nilai atau value sehingga bersifat abstrak dan memiliki banyak arti dan konotasi. Keadilan sering kali dikaitkan dengan kejujuran, kebenaran, kepantasan, atau kelayakan sesuai hak dan lainnya yang banyak digunakan baik untuk memutuskan suatu kejadian atau persoalan. Dominasi keadilan dapat dilihat oleh cita-cita moral belaka bahkan dalam kenyataannya tidak selamanya keadilan berjalan horizontal. Penggambaran secara moral tentang tindakan dari Sani, Rina, dan satpam adalah bentuk nyata bagaimana keadilan sesungguhnya adalah perihal dilematis dan abstrak.

Kekuasan dan stigma negatif masyarakat terlihat dalam seluruh adegan Sani dalam film televisi "Wandu". Adegan awal Sani muncul dengan ledekan tukang ojek menggambarkan bagaimana keadaan waria di masyarakat seperti tokoh Ayu. Layak untuk dicemooh dan tanpa harga diri. Stigma negatif tidak berhenti di situ saja. Mal yang merupakan ruang publik umum tempat semua orang dengan latar belakang berbeda menjadi satu dengan kebutuhan dan tujuan masing-masing, sengaja digunakan sebagai latar belakang konflik.

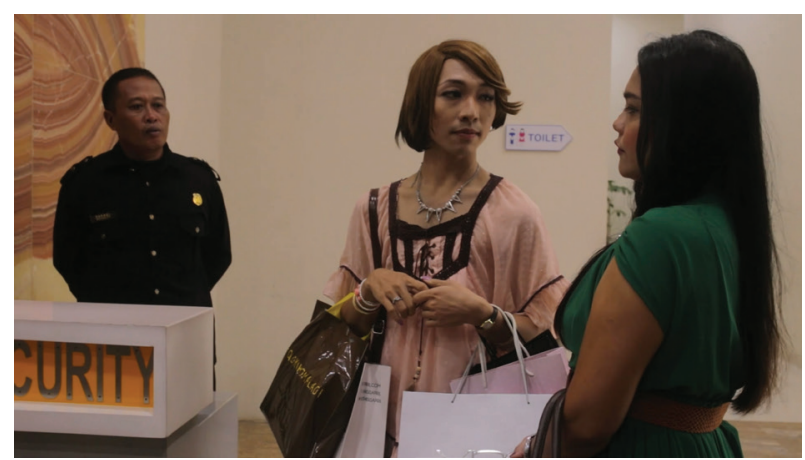

Gambar 5 Satpam, Sani, dan pengunjung mal yang bersitegang (dokumen pribadi)
Mal adalah representasi Indonesia dalam bentuk etalase mikro. Di dalamnya beragam suku, ras, kepercayaan, dan ideologi yang menjadi satu kesatuan. Satpam adalah pamong praja yang berkewajiban menciptakan kondisi aman dan adil layaknya penegak hukum serta kebijakan tentang keberagaman. Toilet, hal privasi setiap individu untuk mengeluarkan dan memercayai ideologinya tanpa mencederai satu sama lain justru menjadi tempat yang patut dicurigai jika perlu dikawal. Rasa kemanusian dan tidak memiliki malu justru Rina tunjukkan. Rina yang secara jelas dan dilihat berpendidikan tidak sedikit pun menunjukkan pola pikir kaum terpelajar. Emosi digunakan ketika nalar sudah tidak mampu untuk berpikir. Penilaian dan kekerasan nonverbal Rina lakukan kepada Sani. Membawa Sani keluar dari toilet umum, menarik lengannya dan berteriak kepada satpam. Layaknya seorang pencuri, Sani dicaci maki di depan satpam. Satuan pengaman atau satpam adalah mereka yang diberikan wewenang untuk menciptakan kondisi kondusif ketika terjadi keributan justru bertingkah arogansi, ikut memeriksa dengan kasar tas Sani tanpa mendengarkan penjelasan kedua belah pihak terlebih dahulu. Satpam adalah wakil dari aparat yang ada di masyarakat guna membantu menumbuhkan kesadaran dan kewaspadaan cipta kondisi serta mengayomi justru berperilaku barbar. Realita ini yang ingin dihadirkan dalam film televisi "Wandu" bagaimana aparat yang harusnya mengayomi malah bertindak sesuka hati dan emosi.

Keadilan merupakan suatu situasi sosial ketika norma-norma tentang hak dan kelayakan dipenuhi (Faturochman, 2002). Pemahaman keadilan sering menekankan pada keadilan distributif, keadilan prosedural, dan keadilan interaksional. Sementara itu, keadilan moral dan 
norma yang justru melekat pada setiap individu tidak memiliki perlindungan dan mekanisme tentang keadilan yang sesungguhnya. Ketika menilai perilaku seseorang, sering kali orang meremehkan pengaruh dari situasi dan terlalu memandang tinggi sejauh mana, perilaku mencerminkan sikap dan sifat dari individu yang bersangkutan. Membentuk opini sendiri serta mengelompokkan seseorang melalui ideologi pribadi tanpa pernah membuka kesempatan kepada pikiran untuk melihat dari sisi yang lain.

\section{SIMPULAN}

Film "Wandu" adalah potret kehidupan waria masa ini dengan problematika di tengah masyarakat yang majemuk. Penggambaran tokoh Ayu, Sani, dan Kemmy merupakan interpretasi dari keberadaan waria di Yogyakarta. Realitas dan kenyataan yang terjadi menjadi medium bercerita bagi film televisi "Wandu". Persoalan waria adalah masalah yang kompleks dan justru tidak sederhana. Maraknya waria juga tidak bisa lepas dari besarnya desakan kebutuhan hidup. Tidak sedikit waria yang ingin mengurus keberadaannya, namun masyarakat masih sulit untuk menerima dengan banyak faktor pertimbangan. Di lain pihak, ancaman, diskriminasi, dan tekanan pada kaum waria tidak pernah susut. Persoalan yang paling dirasakan dan penggerak konflik sesungguhnya adalah identitas mereka. Identitas menjadi hal yang selalu digaungkan oleh waria sebagaimana kaum marginal lainnya. Tentang hak paling dasar manusia, yaitu memperoleh rasa aman, strata sosial, dan fasilitas publik yang seharusnya didapatkan oleh waria sebagaimana manusia lain mendapatkan.

Waria merupakan bagian dari kehidupan, persoalan yang timbul bukan hanya langkah mereka telah salah atau benar, tetapi bagaimana masyarakat mampu memahami kebutuhan mendasar, yaitu rasa aman. Identitas yang dimaksud tidak melulu pada pergantian KTP. Identitas lebih luas pemaknaannya dalam lingkup kehidupan bermasyarakat. Upaya waria untuk menuju keberadaan yang positif selayaknya disikapi baik serta arahan di kalangan sosial bukan sebaliknya.

Dari beberapa waria yang penulis temui sebagai bahan riset memiliki kesamaan sudut pandang. Mereka (waria) juga tidak ingin terlahir demikian dan mereka juga ingin menjadi manusia yang normal. Akan tetapi, dengan status waria atau LGBT yang masyarakat sematkan tidak berarti membuat mereka berhenti tanpa perjuangan lantas berkecimpung di dunia gelap bernama PSK. Tidak semua waria berpikir menjadi PSK, setiap waria memiliki kepala sendiri-sendiri dan mampu berpikir untuk bekerja yang layak bagi hidupnya. Mengubah stigma yang sudah mengakar memang jauh lebih sulit, sesulit mencari keberadaan di tengah masyarakat yang kenyang akan pendidikan instan. Hidup sebagai waria itu memiliki makna yang berbeda dengan hidup menjadi waria.

\section{KEPUSTAKAAN}

Atmojo, Kemala. 1986. Kami Bukan Lelaki: Sebuah Sketsa Kehidupan Kaum Waria. Cetakan 1. Jakarta: Pustaka Grafitipers.

Bastaman, Hanna Djumhana. 1996. Meraih Hidup Bermakna: Kisah Pribadi dengan Pengalaman Tragis. Cet. 1. Jakarta: Paramadina.

El-Idhami, Desmita. 2005. Psikologi Perkembangan. Bandung: Remaja Rosdakarya.

Faturochman. 2002. Keadilan Perspektif Psikologi. Yogyakarta: Pustaka Pelajar.

Fuady, Munir. 2002. Perbuatan Melawan 
Hukum: Pendekatan Kontemporer. Cetakan 1. Bandung: Citra Aditya Bakti.

Hauskeller, Michael. 2015. Seni-Apa itu? Posisi Estetika dari Plato sampai Danto. Diedit oleh Dwiko. Yogyakarta: PT Kanisius.

Koeswinarno. 2004. Hidup Sebagai Waria. Yogyakarta: LKiS.

Kusuma, Wijaya. 2013. "Waria Cantik Ditemukan Tewas di Saluran Irigasi." Kompas.com, Februari 2013.

Marianto, Martinus Dwi. 2017. ART \& LIFE FORCE in a Quantum Perspective. Cetakan 1. Yogyakarta: Scritto Books Publisher.

Nurrizki, Adinda. 2015. "Para Waria Curhat soal Diskriminasi ke GKR Hemas." MerahPutih.com, November 2015.

Pratista, Himawan. 2008. Memahami Film. Yogyakarta: Homerian Pustaka.

Salamah, Ummu. 2012. Pengantar Kesejahteraan Sosial. Bandung: Jurusan Kesejahteraan Sosial Fakultas Ilmu Sosial dan Ilmu Politik Universitas Pasundan. 